\title{
バレイショデンプン粕を主体としたエコフィードサイレージ（EFS） 給与が肥育後期豚の発育と肉質に及ぼす影響
}

\author{
劉 永超 ${ }^{1} \cdot$ Badee GHLAILAT ${ }^{1} \cdot$ 日高 智 2 \\ 1 岩手大学大学院連合農学研究科, 盛岡市 020-8550 \\ 2 帯広畜産大学, 帯広市 080-8555
}

(2013. 9. 10 受付, 2015. 4. 7 受理)

\begin{abstract}
要＼cjkstart約バレイショデンプン粕を主体としたエコフィードサイレージ（EFS）の豚飼料への有効利用につ いて検討した。平均体重 72.8 の同一父親去勢 $\mathrm{LW} \cdot \mathrm{D}$ 交雑去勢豚 18 頭を供試豚として用いた。市販配合飼 料を給与する対照区と，バレイショデンプン粕を主体とした EFS を配合飼料に乾物の 10\%（10\% EFS 区） または 20\%（20\% EFS 区）代替混合した飼料を給与する計 3 試験区を設けた．体重が $110 \mathrm{~kg}$ を超えた時 点で屠畜し, 枝肉成績, 肉質を調査した．飼料摂取量は対照区に比べ, 20\% EFS 区が少なかった $(P<0.05)$ が, 曰増体量に差は認められなかった. 肉質と筋間脂肪の脂肪酸組成には処理間で差はなかったが, 皮下脂 肪の脂肪酸組成において, 10\% EFS 区および 20\% EFS 区の C14:0 と C16 : 1 割合は対照区より高く $(P<0.05), 10 \%$ 区の C18：0 割合は対照区より低い値を示した $(P<0.05)$. 以上の結果から, バレイショ デンプン粕を主体とした EFSは，配合飼料の一部を代替できると考えられた。

日本畜産学会報 86 (3), 335-341, 2015 キーワード: バレイショデンプン粕, エコフィード, ブタ, 肉質, 筋肉内脂肪酸組成
\end{abstract}

\begin{abstract}
バレイショデンプン粕はバレイショからデンプンを抽出 した後の残さである. バレイショデンプン粕の原料である バレイショは, 北海道の畑作の重要な作物の一つで, 全国 生産量の約 80\% (250万t/年) を占めている. 生あるいは 加工食品用以外に，デンプン用としては年あたり 80〜90 万 $\mathrm{t}$ が仕向けられ, 北海道内でバレイショデンプン粕が年 間約 10 万 t 産出されている(農畜産業振興機構 2009). バ レイショデンプン粕は栄養価が高いものの, 水分が多く, そのままでは腐敗しやすいこと, また, 物理的な形状が粘 土質で取り扱いにくいこともあり，飼料としての利用は十 分ではなかった. しかし, 配合飼料原料の輸入価格の高騰 などを背景に, 飼料コスト低減のために栄養価の高いデン プン粕を利用する機運が高まってきた. 一方で，一般的な デンプン工場では, デンプン粕を脱水後に乾燥する設備が 整つていないため, デンプン粕のサイレージ化への取り組 みが行われてきた. 現在では, デンプン粕を脱水し発酵さ せた後, 副原料にふすまやビートパルプなどを加え再発酵 させることで水分を約 60\%に調整し, 発酵品質の向上に 取り組み, 良質なEFS の調製が可能となっている（農畜 産業振興機構 2009)。また, デンプン粕サイレージは肉 用牛での配合飼料の代替可能割合が明らかになっており, 増体成績亡肉質についても報告されている. Sugimoto ら （2009）は，仕上げ期の肉用牛での尿素添加処理ポテトパ
\end{abstract}

ルプサイレージの混合割合の増加は増体成績には影響しな いが, サイレージ混合割合が $30 \%$ 以上では肉質が低下す る可能性があると報告している，しかし，デンプン粕を主 体とした EFSのブタへの給与は, その代替割合也産肉性 に及ぼす影響が十分に明らかになっていない，そこで，本 試験では, バレイショデンプン粕を主体とした EFS の混 合割合が異なる飼料を肥育後期豚に給与し, 発育や肉質に 及ぼす影響を検討した。

\section{材料および方法}

肥育試験は「国立大学法人帯広畜産大学動物実験等に関 する規程」に従つて実施した.

\section{EFS の調製および発酵品質}

EFS の調製は下記のように行った. バレイショからデ ンプンを抽出後に産出されるデンプン粕をスクリュープレ スで脱水し，フレコンバックに詰めてから夏は 6 力月間, 冬は 1 年間発酵させた. 発酵させたデンプン粕を攪找機 に入れ，水分を調整し粗タンパク質今量を高めるために,

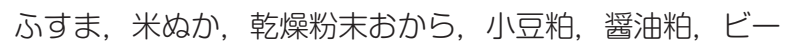
トパルプを添加し（表 1), 十分に混合した後, その後, 2 層プラスチック構造で嫌気性条件を維持できる幅 $\times$ 奥行き ×高さが $110 \times 110 \times 110 \mathrm{~cm}$ で容量が 1331 Lのフレコ ンバックに詰め, さらに夏は 3 力月, 冬は 6 力月再発酵

連絡者：日高 智（fax:0155-49-5429, e-mail : hidaka@obihiro.ac.jp） 
させた。

本試験で対照飼料として，市販配合飼料（成分含量：粗 タンパク質 $13.5 \%$ 以上，粗脂肪 $1.5 \%$ 以上，粗灰分 $7.5 \%$ 以下, カルシウム $0.6 \%$ 以上, リン $0.45 \%$ 以上, TDN $73.5 \%$ 以上：中部飼料株式会社, 名古屋市）を用いた. また, 本試験に使用した飼料の水分, 粗タンパク, 粗脂肪, 粗灰分, 可溶性無窒素物, Organic cell wall (OCW) 含 量を定法により分析した（飼料分析基準研究会編 2005） (表 2). pH の測定は EFS 試料 $30 \mathrm{~g}$ に蒸留水 $170 \mathrm{~g}$ を加 え, 一晚浸透抽出後にろ過した試料を用いて $\mathrm{pH}$ を測定し た. EFS 中の有機酸含量は液体ク口マトグラフで分離定 量し，揮発性塩基性窒素は水蒸気蒸留法 (蔡 2001) で測定

Table 1 Ingredients composition of fermented feed

\begin{tabular}{lc}
\hline \hline Ingredient & Percentage (\%) \\
\hline Potato pulp silage & 79.4 \\
Wheat bran & 9.1 \\
Rice bran & 3.3 \\
Soybean curd residue & 3.3 \\
Adzuki bean meal & 0.9 \\
Soy sauce cake & 1.9 \\
Dried beet pulp & 2.1 \\
\hline
\end{tabular}

FM, fresh matter.
した. 飼料中の脂肪酸は下記のように調整した（Bligh と Dyer 1959). 5 g の飼料をミキサーで, 2 分間程度攪找し, その後ク口ロホルム一メタノ一ル混合液（2:1, v/v）を $8 \mathrm{~mL}$ 入れ，激しく振盪してから，1000×g で 10 分間遠 心分離した，上澄みを新しい試験管に移し，窒素ガスで乾 かし，抽出した全脂質を $5 \%$ 塩酸一メ夕ノ一儿溶液 $1 \mathrm{~mL}$ に懸濁し，アルミブロック恒温槽ドライサーモユニット

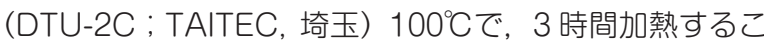
とによりメチルエステル化（Takenoyama 5 1999）し た. メチルエステル化終了後, 室温まで放冷してから $3 \mathrm{~mL}$ のキサンで脂肪酸メチルエステルを抽出し，これ をガスクロマトグラフ (GC-2010；島津製作所，京都) により脂肪酸組成を分析した. 分析はキャリアーガスとし てヘリウムを用い，キャピラリーカラム（ULBON HRSS-10, $0.25 \mathrm{~mm} \times 25 \mathrm{~m}$; 信和化工, 京都) でインジェ クター温度 $250^{\circ} \mathrm{C}$, ディテクター温度 $250^{\circ} \mathrm{C}$, カラム温 度は初期温度 $140^{\circ} \mathrm{C}$ で 2 分, $160^{\circ} \mathrm{C}$ まで $5^{\circ} \mathrm{C} /$ 分, $180^{\circ} \mathrm{C}$ まで $2.5^{\circ} \mathrm{C} /$ 分，さらに $210^{\circ} \mathrm{C}$ ま $5^{\circ} \mathrm{C} /$ 分上昇させ，その 後 10 分間 $210^{\circ} \mathrm{C}$ を保持した。標準試料 GLC85 LOT: A5-U (NU-CHEK PREP, INC, Elysina, MN, USA) を 分析し，その保持時間から各脂肪酸の同定を行った。脂肪 酸はミリスチン酸 $(\mathrm{C} 14: 0)$, パルミチン酸 $(\mathrm{C} 16: 0)$, パルミトレイン酸 $(16: 1)$, ステアリン酸 $(\mathrm{C} 18: 0)$, オレイン酸 $(\mathrm{C} 18: 1)$, リノール酸 (C18:2), $a-1$

Table 2 Chemical composition and fatty acid composition of the experimental diets

\begin{tabular}{|c|c|c|c|c|}
\hline \multirow{2}{*}{ Item } & \multicolumn{3}{|c|}{ Diets } & \multirow[b]{2}{*}{ EFS } \\
\hline & Control & $10 \%$ EFS $^{11}$ & $20 \% E^{2} S^{2)}$ & \\
\hline \multicolumn{5}{|l|}{ Chemical composition $(\%)^{3)}$} \\
\hline Moisture & 12.6 & 23.8 & 34.3 & 66.8 \\
\hline Crude protein & 14.2 & 13.7 & 13.4 & 12.5 \\
\hline Ether extract & 3.1 & 3.2 & 3.3 & 4.5 \\
\hline Nitrogen free extracts & 64.1 & 62.5 & 61.1 & 51.2 \\
\hline Crude ash & 5.1 & 4.3 & 4.9 & 4.4 \\
\hline Organic Cell Wall & 13.8 & 16.4 & 17.7 & 27.9 \\
\hline Total digestible nutrients ${ }^{4)}$ & 75.5 & 75.4 & 75.2 & 74.2 \\
\hline \multicolumn{5}{|l|}{ Fatty acid composition (\%) } \\
\hline C14:0 & 0.06 & 0.09 & 0.09 & 0.17 \\
\hline C16: 0 & 12.94 & 13.80 & 14.52 & 17.60 \\
\hline C16: 1 & 0.21 & 0.23 & 0.20 & 0.18 \\
\hline C18:0 & 1.56 & 1.88 & 1.89 & 2.77 \\
\hline C18: 1 & 28.28 & 28.06 & 26.89 & 25.01 \\
\hline $\mathrm{C} 18: 2$ & 53.69 & 52.46 & 52.44 & 48.43 \\
\hline$a-C 18: 3$ & 2.05 & 2.36 & 2.57 & 3.72 \\
\hline $\mathrm{C} 20: 0$ & 0.30 & 0.31 & 0.32 & 0.41 \\
\hline C20 : 1 & 0.30 & 0.32 & 0.35 & 0.51 \\
\hline
\end{tabular}

1) $10 \%$ EFS : Compound feed $+10 \%$ eco-feed silage.

2) $20 \%$ EFS : Compound feed $+20 \%$ eco-feed silage.

3) Values except for moisture were calculated based on dry matter

4) Calculated value. 
ノレン酸（ $a-\mathrm{C} 18: 3)$, アラキジン酸 (C20:0), エイ コセン酸 (C20 : 1) の 9 種類について同定し脂肪酸割合 を算出した. また, 飼料の構成アミノ酸を調べるために, 塩酸加水分解した後（奥崎亡鈴木 2000），L-8800 ア三ノ 酸分析計（日立製作所，東京）を用い，二ンヒドリン検出 法により測定した.

\section{2. 試験区分および発育調査}

4 力月齢で体重が $72.8 \pm 2.8 \mathrm{~kg}$ (平均土標準偏差) の 同一父親去勢 $\mathrm{LW} \cdot \mathrm{D}$ 種肥育豚 18 頭を用い，6頭ずつ 3 区分し，さらに3 頭ずつ計 6 個のペンで飼養した．デン プン工場で生産された EFS を, 前述の市販配合飼料に乾 物中割合亡して 10\%，20\%となるように混合し，それら の飼料を給与した区を 10\% EFS 区，20\% EFS 区，市販 配合飼料を給与した区を対照区とした。試験期間中の飼養 管理は帯広畜産大学畜産フィールド科学センターの豚舎に おいて, 室温が 5 12Cの環境で, 1 日あたり 16 時間の 照明点灯下で飼育した. 朝 8 時 30 分と夕方 4 時 30 分に 2 回飼料を給与し, 水は自由飲水とした。飼養期間は 2012 年 10 月 10 日〜 11月 22 日の 44 日間で, 試験飼 料を給与した期間は 2012 年 10 月 19 日〜11月 22 日の 35 日であつた. 残飼量の秤量を毎朝行い, 飼料給与量か ら差し引き, 飼料摂取量とした。試験飼料給与開始時と試 験終了時に体重を測定し, 日增体量を求めた. また, 飼料 摂取量と増体量より飼料要求率を算出した。平均体重が $110 \mathrm{~kg}$ を超えた時点で飼育試験を終了し，北海道畜産公 社道東事業所十勝工場にて屠畜解体した.

\section{3. 肉質}

調査項目は枝肉重量, 背脂肪厚および公益社団法人日本 食肉格付協会帯広事業所による格付等級とした. 解体後 $3^{\circ} \mathrm{C}$ で 10 日間熟成した後に，体軸に垂直となる方向で， 第 7 胸椎部から第 12 胸椎部の胸最長筋を $2.5 \mathrm{~cm}$ の厚さ で 3 枚を切り出して, 水分含量, 粗脂肪含量, 肉亡脂肪 の色 $\left(L^{*}, a^{*}, b^{*}\right.$ 值 $)$, クッキングロス, 剪断力価および 皮下内層脂肪亡筋間脂肪の脂肪酸組成を測定した. 脂肪酸 組成の分析は前述の飼料中脂肪酸組成亡同様に行った.

胸最長筋の水分含量は, 第 5 7 胸椎部胸最長筋約 $150 \mathrm{~g}$ を挽肉機で 3 回挽き，サンプルとした. アルミ秤量缶に， サンプルを約 $5 \mathrm{~g}$ 入れ, 精秤し, 海砂と混合した後, ホッ トプレート上で予乾したそれを $100^{\circ} \mathrm{C}$ 恒温乾燥機で 3 時間加熱乾燥し, デシケータで 60 分放冷し秤量した. そ の重量の損失割合を水分含量とした. その後, 直熱式脂肪 抽出装置 SF-8 (三紳工業(株), 神奈川) を用いて, ソッ クスレーエーテル法（畜産技術協会 2003）で 16 時間以 上ジエチルエーテルを還流させ，粗脂肪含量を測定した。

クッキングロスの測定は入江 (2002) とTommy ら （2003）の方法を参考にして行った．すなわち胸最長筋を 形崩れしないようにポリエチレン袋に入れ，ユニット恒温 槽（サーモミンダーSX-10R；TAITEC, 埼玉）を用いて $70^{\circ} \mathrm{C}$ で, 1 時間加熱後, 冷水で 1 時間冷却し. サンプル
表面の内汁の固まりなどを流水で落とし，表面の水分を取 り除いた後, 加熱前後の重量差からクッキングロスの值を 求めた．剪断力価（畜産技術協会 2003）は, クッキング ロス測定後のサンプルを 12 時間 $4^{\circ} \mathrm{C} て ゙$ 泠却した後, 剪断 力価測定用（直径 $1.25 \mathrm{~cm}$ ）コアを用いて筋線維と平行 に回転させながら 6 カ所から試料を採取し, WarnerBratzler meat shear (Model 235 ; G-R Manufacturing Co. Manhattan, Kansas, USA) 剪断力価計を用いて測 定した, 12 回の測定値で, 最小値と最大値を除いた値を平 均し, 試料の剪断力価を求めた. 胸最長筋の肉色は第 12 胸椎部胸最長筋を $4^{\circ} \mathrm{C} 1$ 時間空気に曝した後 EELmeter (CM-1000； MINOLTA，東京）を用いて 5 カ所の L*値 (明度), $a^{*}$ 值 (赤色度), $b^{*}$ 値 (黄色度) を測定し, そ の平均值を求め, 肉色とした.

\section{4. 統計処理}

統計解析は増体成績および肉質について SAS（バ一 ジョン9.2, 2010) の GLM プロシジャを用いて一元配 置分散分析を行った. その後, Tukey 法（吉田1975）に より多重比較検定行い, 有意水準は $P<0.05$ とした.

\section{結果および考察}

\section{EFS の調製および発酵品質}

測定した $\mathrm{pH}$ が 3.8 と低く, 乾物中の乳酸割合が $4.48 \%$ と高い特徵を示した. また, 酢酸とプロピオン酸はそれぞ れ $3.77 \%$ と $0.27 \%$ でサイレージ中の全窒素中の揮発性 塩基性窒素 (VBN/TN) が 7.5\% と低い数值を示した. 良質なサイレージの条件は, 乳酸を多量に含み $\mathrm{pH}$ が低く, 発酵品質を低下させるプロピオン酸と採食量減少に繫がる VBN 含量などが低いものである（森本 1985）。乳酸菌の 増殖が促進されると, 乳酸が生成されて有害な細菌や好気 的微生物の活動を抑制し VBN の生成を抑制する（柾木 2002). デンプン粕は水分が $80 \%$ と高いため, 腐敗しや すい. そのためデンプン粕を原料として良質なサイレージ を調製する方法として乳酸生成系状菌の添加(岡田ら 2005）がある，一方 Yimamu $5 （ 2005 ） は$ は微生物添加 材の有無にかかわらず, ウシの嗜好性が良く, 同程度の栄 養価のサイレージができると報告している. また, 脱水機 により水分を除去した脱水バレイショデンプン粕サイレー ジの調製は，密封することで長期間保存が可能である（杉 本 1983)。ささらに, 乳酸菌製剂を添加しなくても, 乳酸 発酵した良質なサイレージになるとの報告もある（大下 2009）。本試験における EFSは，ビートパルプ，ふすま を水分調整材として加え水分を $60 \%$ に調整し, 密封した ことで, 腐敗しにくくなり, 長期保存可能なサイレージと なった. さらに, 本試験に用いたデンプン粕はデンプン含 量 35\% 以上と高いため, 微生物添加材がなくても乳酸濃 度および酢酸濃度の高い, 良質なサイレージになったと考 えられた。

飼料原料の化学組成および脂肪酸組成を表 2 に示した. 
EFS の CP, 粗灰分含量が配合飼料に比べ低かつたため, 配合飼料の乾物中割合の $10 \%, 20 \%$ EFS で代替する ことにより, 粗タンパク質, 粗灰分の含量は減少した. 方, 粗脂肪および OCW の含量は配合飼料より EFSに多 く含まれていたため，対照区よりも10\% EFS区，20\% EFS 区で多かった，処理区すべての粗タンパク質含量は， 日本飼養標準・豚 (農業·生物系特定産業技術研究機構 2005）における肥育豚の粗タンパク質要求量（体重 70～ $115 \mathrm{~kg}$ で $13 \%$ ）を上回っていた.

給与飼料の脂肪酸組成は, EFS 給与区が対照区に比べ て飽和脂肪酸であるミリスチン酸（C14：0）およびパル ミチン酸 $(C 16: 0)$ の割合が高く, 一価不飽和脂肪酸であ るオレイン酸 $(C 18: 1)$, 多価不飽和脂肪酸であるリノ一 ル酸 $(C 18: 2)$ の割合が低かった. 脂肪酸組成では，い ずれの飼料とも, 構成する脂肪酸はリノ一ル酸 (C18：2), オレイン酸 (C18:1), パルミチン酸 (C16:0) の順で多 くなったが，これは配合飼料に多く含まれるトウモ口コシ の脂肪酸組成を反映したものと考えられた（香川2010）. 飼料中の脂肪酸は, 表 2 に示した主な脂肪酸以外に, 合計 100\% まで, その他 (C11：0, C15：0, C17：0, C17：1, C20:2, C20 : 3, C20:4, C24:1）もわずか含まれて いた.

給与飼料の必須ア三ノ酸含量は全試験区で日本飼養標 準·豚 (農業·生物系特定産業技術研究機構 2005) の要 求量を充足していた（表 3).

\section{2. 発育調查}

EFS 給与が肥育豚の増体成績および枝肉成績に及ぼす 影響を表 4 に示した. 試験区の給与飼料は必須ア三ノ酸 の要求量を満たしていたため, ブタの増体には EFS の影
響はないと考えられた. 終了時体重, 日平均増体量および 飼料要求率について, EFS の代替割合の違いによる有意 な影響はみられなかつた. 乾物摂取量では, 対照区の 3.21 kg/日に比べ, 10\%EFS 区13 kg/日, 20\%EFS 区は 3.01 $\mathrm{kg} /$ 日 20\%EFS 区で有意に少なかった $(P<0.05)$.

Table 3 Amino acid composition of experimental diets"

\begin{tabular}{|c|c|c|c|}
\hline \multirow{2}{*}{ Item, \% } & \multicolumn{3}{|c|}{ Diets } \\
\hline & Control & $10 \%$ EFS $^{2)}$ & $20 \% E^{2} S^{3)}$ \\
\hline \multicolumn{4}{|c|}{ Essential amino acid } \\
\hline Arginine & 0.58 & 0.55 & 0.53 \\
\hline Histidine & 0.34 & 0.33 & 0.32 \\
\hline Isoleucine & 0.41 & 0.42 & 0.42 \\
\hline Leucine & 0.67 & 0.66 & 0.66 \\
\hline Lysine & 1.04 & 1.00 & 0.95 \\
\hline Phenylalanine & 0.51 & 0.51 & 0.51 \\
\hline Threonine & 0.38 & 0.37 & 0.37 \\
\hline Valine & 0.50 & 0.51 & 0.52 \\
\hline \multicolumn{4}{|c|}{ Nonessential amino acid } \\
\hline Alanine & 0.55 & 0.56 & 0.57 \\
\hline Aspartic acid & 0.83 & 0.81 & 0.79 \\
\hline Glutamic acid & 1.96 & 1.88 & 1.80 \\
\hline Glycine & 0.47 & 0.48 & 0.48 \\
\hline Proline & 0.68 & 0.66 & 0.64 \\
\hline Serine & 0.50 & 0.50 & 0.50 \\
\hline Tyrosine & 0.16 & 0.17 & 0.18 \\
\hline
\end{tabular}

1) Content of amino acids based on air-dried matter.

2) $10 \%$ EFS : Compound feed $+10 \%$ eco-feed silage.

3) $20 \%$ EFS : Compound feed $+20 \%$ eco-feed silage.

Table 4 Effect on growth performance and carcass characteristics of finishing pigs

\begin{tabular}{|c|c|c|c|c|c|}
\hline \multirow[b]{2}{*}{ Item } & \multicolumn{3}{|r|}{ Diets } & \multirow[b]{2}{*}{ SEM } & \multirow[b]{2}{*}{$P$-values } \\
\hline & $\begin{array}{l}\text { Control } \\
(n=6)\end{array}$ & $\begin{array}{c}10 \% \text { EFS }^{1)} \\
(n=6)\end{array}$ & $\begin{array}{c}\left.20 \% E_{F}^{2}\right) \\
(n=6)\end{array}$ & & \\
\hline Initial weight (kg) & 73.0 & 72.8 & 72.7 & 1.21 & 0.98 \\
\hline Final weight (kg) & 116.9 & 115.6 & 113.8 & 2.18 & 0.55 \\
\hline Average daily gain (kg/day) & 1.13 & 1.14 & 1.10 & 0.08 & 0.59 \\
\hline Dry matter intake ${ }^{3)}(\mathrm{kg} /$ day $)$ & $3.21^{\mathrm{a}}$ & $3.13^{\mathrm{ab}}$ & $3.01^{\mathrm{b}}$ & 0.04 & $\leqslant 0.01$ \\
\hline Feed conversion ratio ${ }^{3)}$ & 2.88 & 2.77 & 2.75 & 0.13 & 0.74 \\
\hline Dressing percentage (\%) & 62.3 & 63.4 & 62.6 & 1.45 & 0.26 \\
\hline Carcass weight (kg) & 72.8 & 73.3 & 71.3 & 1.51 & 0.65 \\
\hline Back fat depth $(\mathrm{cm})$ & 2.1 & 2.5 & 2.3 & 1.17 & 0.35 \\
\hline Carcass judging ${ }^{4}$ & 2.7 & 2.8 & 2.8 & 1.43 & 0.92 \\
\hline
\end{tabular}

1) $10 \%$ EFS : Compound feed $+10 \%$ eco-feed silage.

2) $20 \%$ EFS : Compound feed $+20 \%$ eco-feed silage.

a, b) Means within a row with no common superscripts are significantly different $(P<0.05)$.

3) Values were calculated based on dry matter. $n=2$.

4) Japan Meat Grading Association body score 1 5. (1 = best, $2=$ good, $3=$ medium, $4=$ normal, $5=$ nonstandard). 
給与飼料の乾物中の NDF 含量は, 対照区が 15.8\%, 10\% EFS 区が 19.1\%，20\% EFS 区が 19.9\% と EFS の配合 率が高くなるとともに飼料中の NDF 含量が多くなり, そ のことが乾物摂取量の減少の要因の一つと考えられる。 し かしながら, 日増体量は処理区間に差は認められず, 配合 飼料への EFS 添加は発育成績に影響を及ぼさないことが 示された. 試験区の給与飼料は必須ア三ノ酸の要求量を満 たしていたことも, 飼養成績に影響がみられなかった要因 と考えられた. また, 解体成績では, 出荷時体重, 枝肉重 量, 背脂肪厚および格付等級に処理区間で有意な差はみら れなかった.

\section{3. 肉質分析}

EFS 給与が肥育豚の肉質に及ぼす影響の結果を表 5 に 示した. Springerら（2003）は肥育豚の胸最長筋にお ける水分含量は $72 \%$ 73\% 程度であると報告しており, 本試験でもそれに近い値であった. 全試験区の胸最長筋の 水分含量は $71 \%$ 73\% と Springer ら (2003) の報告に 近し値であつた.

田淵ら（2002）は, LWD 豚における胸最長筋内脂肪 含量は $2.0 \% \sim 4.2 \%$ と報告している. また, リジン含量 が要求量以下のバレイショ混合サイレージの肥育豚への給 与で, 筋肉内脂肪含量が増加することが明らかとなってい る(嶋澤ら 2008). 本試験では, いずれの飼料において も日本飼養標準・豚 (農業・生物系特定産業技術研究機構 2005）のリジン要求量を上回っていたため, 区間に差は みられず, その值も2.9 3.7\%と田端ら（2002）の報告 と同等となった. 肉色および脂肪色は, 市場において重要 な評価項目の1つである. Moon 5（2004）は食品残椬 の発酵鸰料の給与により, 道後ら (1995) はトウモロコシ
あるいは大麦を多給することにより, 肉色が変化すると報 告している. また, 嶋澤ら (2007) および三津本ら (1987) は, 胸最長筋の肉色は筋肉内脂肪含量および体重に依存す る傾向があると報告している. 本試験で給与した EFSに は食品残さおよび大麦の含量が少なく, 筋肉内脂肪含量お よび体重において差がなかったため, 肉色に影響がみられ なかったと考えられる.

胸最長筋のクッキングロスおよび剪断力価は処理区間 に有意な差はみられなかった。條々ら (1994), 畑江ら (1996), 沖谷 (1996) および日高ら (2006) はクッキ ングロスが小さいほど多汁性が高＜，官能試験のジュー シ一さとの間に相関があるとしている。乾燥ワカメ茎を添 加した試験（鈴木5 2002）では，乾燥ワカメ茎 $0.3 \%$ の 添加により無添加の場合と比べクッキングロスが有意に少 なくなることが報告されている，本試験で給与した EFS にはクッキングロスに影響を及ぼす成分を含んでいるとは

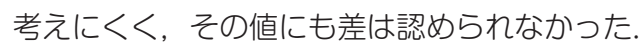

EFS 給与区の皮下脂肪（表6）は，ミリスチン酸 (C14：0) およびパルミトレイン酸 $(C 16: 1)$ が対照区 に比べ有意 $(P<0.05)$ に多く, 10\%区ではステアリン 酸（C18：0）が対照区より有意 $(P<0.05)$ に少なかつ たが, 他の脂肪酸割合に差はみられなかった．この結果は, 肥育豚への乳酸生成糸状菌添加ポテトパルプサイレージと 食品残さの乾燥調製飼料給与で配合飼料給与よりもミリス チン酸（C14：0）割合が有意に多くなるとの報告（日高 5 2006) と一致した. ブタの体脂肪の脂肪酸組成は, 飼 料中の油脂の質と量に大きく影響され（入江 1992 ; 山田 5 2001), 脂肪組織の不飽和脂肪酸割合が多いほど柔ら かくなり望ましくないとされている，特に飼料中のリノー

Table 5 Effect on meat quality characteristics of finishing pigs

\begin{tabular}{lrrrrr}
\hline \hline \multirow{2}{*}{ Item } & \multicolumn{3}{c}{ Diets } \\
\cline { 2 - 4 } & $\begin{array}{c}\text { Control } \\
(n=6)\end{array}$ & $\begin{array}{c}10 \% \mathrm{EFS}^{1)} \\
(n=6)\end{array}$ & $\begin{array}{c}20 \% \text { EFS } \\
(n=6)\end{array}$ & SEM & P-values \\
\hline Moisture (\%) & 72.0 & 72.9 & 73.0 & 0.33 & 0.09 \\
Ether extract (\%) & 3.7 & 2.9 & 3.4 & 0.35 & 0.33 \\
Cooking loss (\%) & 24.6 & 24.6 & 25.6 & 0.37 & 0.15 \\
Warner-Bratzler shear (N) & 1.9 & 2.0 & 1.7 & 0.14 & 0.47 \\
Meat color ${ }^{3)}$ & & & & & \\
L $^{*}$ & 54.5 & 54.1 & 55.0 & 0.70 & 0.66 \\
a $^{*}$ & 8.4 & 7.7 & 7.4 & 0.41 & 0.23 \\
b* $^{*}$ & 8.7 & 7.9 & 8.0 & 0.38 & 0.33 \\
Fat color $^{3)}$ & & & & & \\
L $^{*}$ & 80.0 & 79.3 & 78.3 & 0.48 & 0.07 \\
a $^{*}$ & 2.3 & 2.7 & 3.0 & 0.25 & 0.15 \\
b $^{*}$ & 7.5 & 7.5 & 7.5 & 0.26 & 1.00 \\
\hline
\end{tabular}

1) $10 \%$ EFS : Compound feed $+10 \%$ eco-feed silage.

2) $20 \%$ EFS : Compound feed $+20 \%$ eco-feed silage.

3) $L^{*}$ : Brightness, $a^{\star}$ : Redness, $b^{*}$ : Yellowness. 


\section{劉・GHLAILAT ・日高}

Table 6 Effect on subcutaneous and intramuscular fatty acid composition of finishing pigs

\begin{tabular}{|c|c|c|c|c|c|}
\hline Fatty acid (\%) & $\begin{array}{l}\text { Control } \\
(n=6)\end{array}$ & $\begin{array}{c}10 \% \mathrm{EFS}^{1)} \\
(n=6)\end{array}$ & $\begin{array}{c}20 \% \mathrm{EFS}^{2)} \\
(n=6)\end{array}$ & SEM & $P$-values \\
\hline \multicolumn{6}{|l|}{ Subcutaneous Fat } \\
\hline C14: 0 & $1.3^{\mathrm{b}}$ & $1.5^{\mathrm{a}}$ & $1.5^{\mathrm{a}}$ & 0.04 & 0.02 \\
\hline C16: 0 & 27.6 & 28.3 & 28.2 & 0.35 & 0.33 \\
\hline C16: 1 & $1.4^{b}$ & $1.9^{a}$ & $1.9^{\mathrm{a}}$ & 0.09 & $\leqslant 0.01$ \\
\hline $\mathrm{C} 18: 0$ & $18.4^{a}$ & $15.8^{b}$ & $16.2^{\mathrm{ab}}$ & 0.61 & 0.02 \\
\hline C18: 1 & 40.6 & 41.8 & 41.3 & 0.81 & 0.57 \\
\hline C18: 2 & 10.7 & 10.7 & 11.1 & 0.34 & 0.67 \\
\hline SFA ${ }^{3)}$ & 47.3 & 45.6 & 45.8 & 0.84 & 0.33 \\
\hline MUFA ${ }^{4)}$ & 42.0 & 43.7 & 43.1 & 0.85 & 0.39 \\
\hline PUFA ${ }^{5)}$ & 10.7 & 10.7 & 11.1 & 0.34 & 0.67 \\
\hline \multicolumn{6}{|l|}{ Intramuscular Fat } \\
\hline C14:0 & 1.4 & 1.6 & 1.6 & 0.06 & 0.35 \\
\hline C16: 0 & 28.0 & 29.0 & 28.7 & 0.38 & 0.20 \\
\hline C16: 1 & 1.8 & 2.1 & 2.0 & 0.11 & 0.17 \\
\hline C18:0 & 17.7 & 15.9 & 15.8 & 0.63 & 0.09 \\
\hline $\mathrm{C} 18: 1$ & 41.9 & 41.7 & 41.0 & 0.98 & 0.80 \\
\hline C18:2 & 9.2 & 9.8 & 10.9 & 0.50 & 0.09 \\
\hline SFA ${ }^{3)}$ & 47.1 & 46.4 & 46.1 & 0.91 & 0.73 \\
\hline MUFA $^{4)}$ & 43.7 & 43.8 & 43.0 & 1.02 & 0.84 \\
\hline PUFA ${ }^{5)}$ & 9.2 & 9.8 & 10.9 & 0.50 & 0.09 \\
\hline
\end{tabular}

1) $10 \%$ EFS : Compound feed $+10 \%$ eco-feed silage.

2) $20 \%$ EFS : Compound feed $+20 \%$ eco-feed silage.

a.b) Means within a row with no common superscripts are significantly different $(P<0.05)$

3) SFA : Saturated fatty acid.

4) MUFA : mono unsaturated fatty acid.

5) PUFA : polyunsaturated fatty acid.

ル酸 $(C 18: 2)$ やリノレン酸 $(C 18: 3)$ などの多価不 飽和脂肪酸は, 飽和脂肪酸と比べてブタの脂肪組織に選択 的に蓄積されやすく, 脂肪を柔らかくするとされている(松 岡5 1985 ; 丹羽と中西 2002)。入江と藤谷（1989）は, 豚の体脂肪は摂取する飼料の影響を受けやすいと報告し, 特に多価不飽和脂肪酸の多いおから, 大豆油を飼料に添加 すると筋肉内脂肪を含むすべての部位の脂肪において, リ ノール酸 (C18:2) およびリノレン酸 $(\mathrm{C} 18: 3)$ 割合 が増加すると報告している。

以上の結果から, 配合飼料の $20 \%$ をバレイショデンプ ン粕を主体とした EFS で代替した飼料を給与しても成長 には影響は認められないことが示された. 今後は EFS の 代替割合を 30\% まで高めた際の飼養成績および肉質への 影響を検討する必要があると考えられた。

\section{文献}

Bligh G, Dyer J. 1959. A rapid method for total lipid extraction and purification. Canadian Journal of Biochemistry and Physiology 37, 911-917.
蔡 義民. 2001. サイレージの分析法. 改訂粗飼料の品質評価 ガイドブック. pp. 36-42. 日本草地畜産種子協会, 東京.

畜産技術協会. 2003. 牛肉の品質評価のための理化学分析マ二ユ アル Ver. 2.（社)畜産技術協会，東京.

畑江敬子. 1996. 食肉の調理. 肉の科学. pp. 112-127. 朝倉 書店, 東京.

日高 智, 大田 忍, 三浦俊治, 小田有二. 2006. 乳酸生成糸状 菌 (Amylomyces rouxii) 添加ポテトパルプサイレージと 食品残渣からの乾燥調製飼料粭与が肥育豚の産肉性に及ぼす 影響. 北海道畜産学会報 48, 59-63.

入江正和, 藤谷康裕. 1989. 豚の脂肪組織亡筋肉脂肪の理化学的 性状に及ぼす大豆油添加と添加時期の影響. 日本養豚学会誌 26. 255-260.

入江正和. 1992. 豚における脂肪の質，特に給与飼料の影響に関 する研究. 日本養豚学会誌 29,92-95.

入江正和. 2002. 豚肉質の評価法. 日本養豚学会報 39,221254.

香川芳子. 2010. 五訂增補食品成分表. pp. 182-183. 女子栄 養大学出版社, 東京.

柾木茂彦. 2002. 改訂粗飼料の品質評価ガイドブック, 自給飼料 品質評価研究会編. 91-93. (社) 日本草地畜産種子協会, 東京.

松岡昭善, 鈴木伸一, 池田周平, 濱岡俊哉. 1985. 豚に対する発 酵飼料の利用に関する研究 2. 食品残渣物を中心に配合した 


$$
\text { バレイショデンプン粕を主体としたエコフィードサイレージ }
$$

場合のと肉成績ならびに肉質について，日本養豚研究会誌 22, 213-220.

道後泰治, 鳥飼善郎, 岡 章生. 1995. 給与飼料の違いが肥育牛 の肉色に及ぼす影響. 兵庫県農業技術セン夕一研究報告 31 , 53-56.

三津本充, 三橋忠由, 山下良弘. 1987. 黒毛和種去勢牛の発育に ともなう 4 種の筋肉における肉色の変化. 近畿中国四国農業 研究セン夕一研究報告 1, 59-67.

Moon JS, Know IK, Cha BJ. 2004. Effect of wet feeding of diets with or without feed waste on growth performance and carcass characteristics in finishing pigs. AsianAustralasian Journal of Animal Science 17, 504-510.

森本 宏. 1985. 飼料学. 第 1 版. 乾草およびサイレージ調整 法とその栄養的品質. pp. 218-219. 養賢堂, 東京.

丹羽美次, 中西五十. 2002. 豆腐粕, パン屑主体サイレージおよ びパス夕屑の給与が肥育豚の発育および体脂肪に及ぼす影 響. 日本養豚学会誌 39, 157-165.

農畜産業振興機構. 2009. 民間（商系）でん粉工場におけるでん 粉かす有効利用調査. 農畜産業振興機構, 東京; [cited 6 . March 2010]. Available from URL: http://www.alic. go.jp/starch/japan/report/200909-01.html

農業·生物系特定産業技術研究機構編. 2005. 日本飼養標準·豚. 2005 年版. pp. 40-41. 中央畜産会, 東京.

岡田 舞, 渡辺 彩, 松岡 栄, 三浦俊治, 小巴有二, 河合正人. 2005. 乳酸生成糸状菌 (Amylomyces rouxii) 添加ポテト パルプサイレージ貯蔵中における化学成分および発酵品質の 経時の変化. 北海道畜産学会報 47, 59-64.

沖谷明紘. 1996. 食肉のおいしさと熟成. 肉の科学. pp. 5987. 朝倉書店, 東京.

大下友子、2009. ばれししょでんぷん粕サイレージの利用に向け て. 農畜産業振興機構調査情報部。農畜産業振興機構調査情 報部情報課編 27, 1-4.

奥崎政美, 鈴木忠直. 2000. 新食品八ンドブック. 食品成分の測 定. pp. 38-40. 建帛社, 東京.

嶋澤光一, 本多昭幸, 竹野大志, 西川 轍, 尾野喜孝. 2008. 八゙ レイショ混合サイレージの肥育豚への給与が豚肉の理化学的 特性に及ぼす影響. 日本畜産学会報 79, 385-390.

嶋澤光一, 本多昭幸, 竹野大志, 西川 轍, 尾野喜孝. 2007. 八゙ レイショ混合サイレージ給与が肥育豚の発育および肉質に及 ぼす影響. 日本畜産学会報 78, 355-362.

飼料分析基準研究会編. 2005. 飼料分析法. 解説 (2004). 飼料
（EFS）給与が肥育後期豚の発育と肉質に及ぼす影響

分析基準収載分析法. pp. 1123-1126. 日本科学飼料協会, 東京.

Springer MP, Carr MA, Ramsey CB and Miller MF. 2003. Accelerated chilling of carcasses to improve Pork quality. Journal of Animal Science 81, 1464-1472.

杉本亘之. 1983. 脱水馬鈴薯澱粉粕サイレージの豚における飼料 価値. 滝川畜産試験研究報告 20, 1-4.

Sugimoto M, Saito W, Ooi M, Sato Y, Saito T. 2009. The effects of inclusion levels of urea-treated potato pulp silage in concentrate and roughage sources on finishing performance and carcass quality in cull beef cows. Animal Science Journal 80, 280-285.

鈴木啓一, 清水ゆう子, 門脇 宏. 2002. 乾燥ワカメ茎亡パン屑 添加飼料給与が豚の産肉・肉質形質に及ぼす影響. 日本養豚 学会誌 39, 66-70.

鈴木邦夫, 高橋圭二, 園原邦治, 松岡邦裕, 宮原 強. 1994. 高 品質豚肉生産技術の確立に関する研究。千葉県畜産セン夕ー 研究報告 18,39-44.

Takenoyama S, Kawahara S, Murata S, Yamauchi K. 1999. Investigation of some preparation procedures of fatty acid methyl esters for capillary gas-liquid chromatographic analysis of conjugated linoleic acid in meat. Animal Science Journal 70, 336-342.

田淵賢治, 三谷英嗣, 川口政司. 2002. 豚肉の理化学的検査亡官 能検査との相関について (短報)。香川県畜産試験場研究報告 37, 34-40.

Tommy L, Steven W, Shackelford D, Mohammad K. 2003. Warner-Bratzler Shear Force Protocol. United States Department of Agriculture-Agricultural Research Service U.S. Meat Animal Research Center, Clay Center, NE.

山田末知, 網中 潤, 山田幸二. 2001. 豚の脂肪組織と筋肉にお ける脂肪酸組成に及ぼすエゴマ種実の影響. 日本養豚学会誌 38, 25-30.

Yimamu A, 田村 暁, 花田正明, 岡本明治. 2005. 反媰家畜 におけるポテトパルプサイレージの栄養価および給与効果. 東海畜産学会報 16, 23-25.

吉田 実. 1975. 畜産を中心亡する実験計画法. 養賢堂, 東京.

條々和実, 北村雅彦, 石田昌弘, 安武純孝. 1994. 優良系統豚を 活用した良食味豚肉生産技術の確立. 山梨県畜産試験場研究 報告 $\mathbf{4 1}, 9-12$. 